\title{
Editorials
}

\section{Doctors and suicide}

On Monday 28 April 1902, Dr Jeannie Charlotte MacLeod (Jeannie) buttoned her starched white coat, checked her pockets for her stethoscope and notebook, took one last look at herself in the mirror, and walked onto the paediatric ward as the new House Officer at Aberdeen Children's Hospital. She glowed with pride as she introduced herself to the Senior Ward Matron, able to use the title of Doctor for the first time. By the end of that week, Jeannie was dead. At the age of 28 and alone in her on-call room, she had cut her jugular vein and bled to death. She was found by the porter who had been sent from the ward to find her (personal communication, Dr Bob Clarke [great nephew], December 2017). Four years later and a world apart, a Russian doctor, Dr Veressayev, wrote about the high rate of suicide among his classmates, $10 \%$ of whom died by their own hand. ${ }^{1}$ Why these doctors chose to kill themselves can only be surmised. Jeannie did not write a suicide note, but we know from her letters to her family that she had a tough time during her medical school training. As the only woman in her year, and only the third woman to qualify as a doctor in Scotland, she had to be taught separately for much of her training, was mocked and laughed at by her male colleagues, and we can only imagine how she would have been received by the allfemale nursing staff. Family folklore tells of Jeannie experiencing the death of a child during her first week on duty and the guilt being too much for her to bear. In his book, Dr Veressayev talks only in generalities, touching on the unrelenting workload, pressure of the patient expectations, worries about complaints, and low pay.

Today, the problem of suicide among doctors is still a cause of concern.

\section{RISK FACTORS FOR DOCTORS}

Throughout time and across the world, doctors have always had higher rates of suicide compared with the general population and with other professional groups. Female doctors in particular have higher rates -2.5 -4.0 times the rate by some estimates. ${ }^{2}$ The reasons for suicide among doctors - as in the general population - are often related to un- (or under-) treated depression, bipolar disorder, or substance misuse. ${ }^{3}$

However, for doctors the risk factors go beyond mental illness. ${ }^{4}$ As a group, doctors

\section{"Doctors are human. Doctors should not have to sacrifice their lives for their profession.}

occupy a privileged position in society. They bear witness to the suffering of patients who share secrets told to no one else, not even their closest relatives. Doctors are often faced with the futility of their endeavours. Without a safe outlet to talk about the emotional impact of their work, doctors may carry the stress of their work beyond the consulting room, putting them at risk of depression, substance misuse, and even suicide. Doctors have other specific risk factors, such as access to land training in the use of) dangerous drugs, explaining why anaesthetists have higher rates of suicide than paediatricians. ${ }^{5}$

The impact of complaints and referral to the regulator can also have a major impact on doctors' mental health. In 2015, a newly qualified GP who had been voted 'Trainee GP of the Year', Dr James Halcrow, hanged himself. The inquest heard how he feared erasure from the medical register for transgressing the conditions set down by the General Medical Council (GMC), which were reported to dictate that he abstain from alcohol. ${ }^{6}$

On 24 November 2015, Dr Wendy Potts, a GP and mother of two, killed herself.? Dr Potts suffered from bipolar disorder and kept a blog about her condition. Apparently, a patient had complained and Dr Potts was suspended and later referred to the GMC The coroner told the inquest

'It seems to me the suspension and investigation was something of a sledgehammer being used to crack a nut. ${ }^{8}$

The theme of losing sight of the person behind the professional is echoed by Mahajan and Johnstone when they describe how a doctor became lost in the system,' which, in their view, contributed to his suicide.?

\section{COMPLAINTS AGAINST DOCTORS}

Bourne et al conducted a large study of doctors in the UK and discovered the deleterious impact that complaints and/or referrals to the regulator have on doctors' mental state. ${ }^{10}$ Doctors who had recently received a complaint of any kind were found to be $77 \%$ more likely to suffer from moderate to severe depression than those who had never had a complaint. They were also found to have increased incidence of suicidal thoughts, sleep difficulties, relationship problems, and a host of physical health problems compared with people who had not been through a complaints process. Over a 9-year period, 21 doctors in the care of the NHS Practitioner Health Programme (PHP; http://php.nhs.uk/) have died. Among living PHP patients, the GMC is involved in around $10 \%$ of cases, compared with $52 \%$ (11 out of 21) of patients who have died and $56 \%$ (9 out of 16 ) of the patients who died from accidents, suicide, or overdoses. Between 2005 and 2013, 28 doctors died through suicide or suspected suicide while undergoing GMC investigation. ${ }^{11}$ Although correlation does not mean causation, being under regulatory or disciplinary processes nevertheless increases the risk of mental illness among doctors and a complaint or referral to the GMC must be considered a red-flag risk factor for both depression and

\section{"If they [doctors] are to give their all to patients and make patients their first concern, then the quid pro quo is that the system (the NHS) cares for them and does everything morally, ethically, and practically that it can to remove or, at the very least, reduce the causes of their distress.}




\section{"Don't suffer in silence; seek help.}

suicide. The GMC has since implemented a series of changes in their processes to limit and hopefully reduce the mental health impact of a referral to them.

\section{DOCTORS ARE HUMAN TOO}

Though thankfully a rare event, the repercussions following suicide are immense. Far from being a one-off tragedy in itself, suicide can cause guilt, shame, and higher rates of suicide in loved ones left behind, as well as the potential of contagion. Jeannie, James, Wendy, and all the other doctors who have killed themselves teach us a salutary lesson, mentioned by the coroner presiding at Dr Pott's inquest. Doctors are human. Doctors should not have to sacrifice their lives for their profession. If they are to give their all to patients and make patients their first concern, then the quid pro quo is that the system (the NHS) cares for them and does everything morally, ethically, and practically that it can to remove or, at the very least, reduce the causes of their distress. This means addressing the regulatory process, in particular the delays in the system, the disproportionate sanctions which mean

\section{Box 1. Available help}

\section{Samaritans}

Tel: 116 123; Email: jodsamaritans.org

\section{NHS GP Health Service (GPH) \\ Email: gp.healthanhs.uk;}

http://gphealth.nhs.uk/

\section{NHS Practitioner Health Programme (PHP)} http://php.nhs.uk/; Tel: 03000303300

(GPH and PHP form part of the same service - Practitioner Health Service, which offers free confidential support for doctors with mental health problems.)

\section{DocHealth}

\section{www.dochealth.org.uk}

\section{Royal Medical Benevolent Fund (RMBF)} https://rmbf.org/

(The RMBF provides packages of support in addition to significant funding, and is open to all doctors, including refugee doctors and medical students in their final 2 clinical years.)

\section{Louise Tebboth Foundation}

http://www.louisetebboth.org.uk that even 'only' a 12-month suspension might result in the doctor never being able to work again. The 'multiple jeopardy', where a doctor could spend many years defending themselves at different parts of the medical, legal, and regulatory systems, must also be addressed.

The days of the doctor being the superhuman, all-giving, sacrificing individual are over. It is now time to have a more realistic contract with our patients and with the health systems in which we work, a contract where the doctor is cared for and can expect the same compassion as the patients they treat.

Don't suffer in silence; seek help. If you or someone you know might need help with a mental health concern, including stress or depression, or an addiction problem, help is available (see Box 1).

The International Practitioner Health Summit 2018: The Wounded Healer is being held on Thursday 4 October to Friday 5 October 2018 in London (http:// www.healthcareconferencesuk.co.uk/ practitioner-health-summit).

\section{Clare Gerada,}

Medical Director of GP Health Service and NHS Practitioner Health Programme, and Senior Partner, Hurley Group, London.

\section{Provenance}

Commissioned; not externally peer reviewed.

\section{Competing interests}

The author has declared no competing interests.

\section{Acknowledgements}

The author acknowledges the Louise Tebboth Foundation (http://www.louisetebboth.org.uk) as supporting the mental wellbeing of medical practitioners and doctors' families bereaved by suicide.

DOI: https://doi.org/10.3399/bjgp18X695345

\section{ADDRESS FOR CORRESPONDENCE}

Clare Gerada

Riverside Medical Centre, St George Wharf, London SW8 2JB, UK

\section{Email: claregeradaQdgmail.com} Aclarercgp

\section{REFERENCES}

1. Veressayev W. The memoirs of a physician. New York: Alfred A Knopf, 1916

2. Norris S, Elliott L, Tan J. The mental health of doctors: a systematic literature review. Health Technology Analysts, Pty Ltd, 2010.

3. Hawton K, Clements A, Simkin S, Malmberg A. Doctors who kill themselves: a study of the methods used for suicide. QJM 2000; 93(6): 351-357.

4. Department of Health. Mental health and ill health in doctors. London: DH, 2008

5. McNamee R, Keen RI, Corkill CM. Morbidity and early retirement among anaesthetists and other specialities. Anaesthesia 1987; 42(2): 133-140.

6. Keogh G. Suicide tragedy of award-winning young doctor who feared he could fail alcohol test. Manchester Evening News 2015; 24 Nov: https://uww.manchestereveningnews. co.uk/news/greater-manchester-news/ james-halcrow-doctor-suicide-drink-10494416 laccessed 7 Mar 2017].

7. Miller MN, Mcgowen KR, Quillen JH. The painful truth: physicians are not invincible. South Med J 2000; 93(10): 966-973.

8. Dyer C. Practice that suspended GP who later died by suicide used 'a sledgehammer to crack a nut', says coroner. BMJ 2017; 357: j3141. DOI: https://doi.org/10.1136/bmj.j3141.

9. Mahajan S, Johnstone C. Human factors in suicide prevention. InnovAiT 2017; 10(11) 679-686.

10. Bourne T, Wynants L, Peters M, et al. The impact of complaints procedures on the welfare, health and clinical practise of 7926 doctors in the UK: a cross-sectional survey. BMJ Open 2015; 4: e006687.

11. Horsfall S. Doctors who commit suicide while under GMC fitness to practice investigation. London: General Medical Council, 2014. 